\title{
SPIRITUAL POEMS \\ IN THE RUSSIAN AND SLAVIC TRADITION ${ }^{1}$
}

\begin{abstract}
:
Spiritual verses are a genre associated with an oral folk tradition, and they are often found in written form as part of handwritten spiritual verse collections, which were often accompanied by Russian "hook" notation. In Russian and Slavic folklore, they relate in content and style to church liturgy books and occupy a middle ground between such writings and folklore. Russian spiritual verses arose, most probably, back in the pre-Mongol period. Designed to support the spirit of piety in people, in the past they were performed by travelling singers, so-called "kaliki perehozhiye". The Old Believers serve as custodians of the oldest examples of spiritual verses up to this day. The poems can be performed at a funeral, on remembrance, during a meal. They served as a particular link that connected the Church and everyday life for the believer. The article examines some types of the Old Believers' spiritual poems, which are not infrequently compared to examples from eastern and southeastern European folk songs.
\end{abstract}

\section{Keywords:}

Spiritual verses, travelling singers, oral and written tradition, Russian Old Believers.

АнНОТация: Л.К. ГАВРЮшиНА. «ДУХОВНЫЕ СТИХИ В РУССКОЙ И СЛАВЯНСКОЙ ТРАДИЦИИ». Духовные стихи - жанр, связанный с устной народной традицией, часто находящей отражение в письменной форме, входя в состав рукописных стиховников, тексты нередко сопровождаются крюковой нотацией. В русском и славянском фольклоре они содержательно и стилистически связаны с церковной книжностью и занимают между ней и фольклором промежуточное положение. На Руси духовные стихи возникли, скорее всего, еще в домонгольский период. Призванные поддерживать дух благочестия в народе, они исполнялись в древности бродячими певцами «каликами перехожими». Хранителями наиболее древнего пласта духовных стихов вплоть до нашего времени являются старообрядцы. Стихи могли исполняться в день погребения, на поминках, за трапезой; они служили своеобразным звеном, которое соединяло для верующего человека церковную и повседневную жизнь. В статье рассматриваются некоторые типы старообрядческих духовных стихов, которые нередко сравниваются с примерами из восточнои юго-восточной европейской народной словесности.

\section{Ключевые слова:}

Духовные стихи, «калики перехожие», стиховники, старообрядчество.

Q piritual poems, a genre that is spread, in particular, in the literature of the Eastern Slavs, belong to both the oral and book traditions and are a kind of way of expressing people's theological ideas. Through poetry, people have created their religious vision of the world.

\footnotetext{
1 The work was carried out with the financial support of the RFBR (grant № 18-512-76004).
} 
When getting acquainted with various examples of folk spiritual poetry, the literary and musical breadth of this genre particularly stands out. G.P. Fedotov called Russian spiritual poems songs on religious subjects. This definition is true only in a general sense, since the poems are very diverse as to when they were written, their content and artistic features. They owe their origin to ecclesiastical bookishness and are closely related to it in stylistic terms.

Intended for the purpose of supporting the spirit of godliness among the people, in old times the verses were performed by migratory singers, "wandering minstrels." Among them, for example, are verses that resemble the Lives, since they describe a certain period in the life of a saint or his whole life from birth to death. The most famous example is the "Verse about Alexey, the Man of God," who devoted himself to God, abandoning his bride and leaving his parents, and after many years came to his native house, where he lived as a slave, unrecognized by his relatives. One of the oldest verses in the Russian tradition about saints is a spiritual verse about the first Holy Martyrs, the princes Boris and Gleb, who were killed by their elder brother, Svyatopolk, for the sake of succeeding to the princely throne. In the poems that appeared during the schism of the Russian Church in the 17 th century and immediately thereafter, considerable importance is given to eschatological themes, the coming into the world of the Antichrist, and the ways of saving and purifying the soul in anticipation of the Last Judgment:
"Already the Antichrist sits on the kingdom, He gives such a charm, There will be a great order - persecution. Throughout the whole earth, through the universe."

Up to this day the Old Believers have been the custodians of the most ancient set of spiritual verses. At the end of the last century it was possible to find Old Believer communities in which the singing of verses was an important part of their established way of life. Verses were sung after the service, at funerals, at meals, at wakes. They served as a kind of link connecting church and everyday life.

In many poems, in particular poems about the afterlife of man, confessional and penitential principles prevail. Although the basis of folk compositions of this kind is not always a specific plot, in each of them there is a stable image of a certain religious idea, embodied in one of the many textual and melodic variations.

The moralizing principle did not prevail in every verse. This genre contained many things, from confession and repentance (as already mentioned) to fascinating history and folk legend. A fanciful image of popular faith is found in a verse about three trees used to build a church, in which, in turn, the Virgin, Jesus Christ himself and John the Baptist lie in three coffins. It is believed that in this way not wanting to part with them - the people expressed their love for Christ, the Mother of God and John the Baptist. 
Thus a significant vein of folk poetry exists wholly or mainly in oral form. However, as already mentioned, poems are also preserved in the written tradition. The Old Believers' spiritual poems could be sung by hook verses, in which hook notation was accompanied by a text written in Church Slavonic. Among them, for example, is the verse Sidya Adam pryamo raya ("Adam was sitting opposite paradise"), which existed, in particular, among the priestless Old Believers in the Nizhny Novgorod region.

In many cases, verses are sung from the text of a handwritten or printed poetry to a chant, which is passed down from one generation to the next.

The repertoire of poems recited by one or another performer is determined by his age, participation in church life (for example, singing in the choir during worship), as well as personal preferences. It is also important that the singing of poetry in many families was a tradition. To this day, in the homes of Old Believers, manuscript notebooks with verses are handed down from fathers and mothers to children.

The existence of spiritual verses in a peasant environment is a unique cultural phenomenon. In some rural communities there are illiterate people who throughout their lives retain lengthy verses in their memory, each time performing them slightly differently. However, when creating new versions, performers rely on a concrete text existing in the book tradition. In this regard, the spiritual verse To Whom My Sorrow, dedicated to Joseph the Beautiful (a story from the Old Testament), is very interesting; it has many oral versions, and its text, including printed verses, is one of the most extensive in the Russian tradition.

Folk performers themselves sometimes leave notes in manuscript verses reflecting their idea of the significance of this genre in the life of a believer. So, in them you can read that the spiritual verses are of ancient origin and are imbued with a deep prayerful feeling. It is reported that in olden times verses were sung with reverence, that they supported those singing and listening to them in difficult times.

A rather significant vein of spiritual verses is devoted to the afterlife of the human soul. Russian peasants were very skeptical about the possibility of their own salvation in a future life. While they certainly regarded Christ as their Savior, they were hard on themselves, recognizing themselves as sinners who should not place any hope in a heavenly abode. That is why paradise in spiritual verses seems unattainable - this is merely a certain land which you can admire as you pass by, while lamenting over the fact that the doors are closed there:

"I pass by paradise,

Bitterly I cry and grieve,

Oh, woe, woe to me, great!"

Among the poems widely spread in Russia is the so-called The Virgin's Dream, which relates the sufferings of the Virgin and contains both her monologue stories about the Passion of Christ and her dialogues with the Savior. Its final lines 
contain a reminder of the need to read this verse several times a day to get rid of all kinds of dangers and ailments. This verse, which was also used as a talisman, was widely circulated in manuscript form.

One of the oldest themes of spiritual verses in the Slavic tradition as a whole about the parting of the soul from the body - is closely connected to the ancient legend of the journey to the afterlife, about the transmission of the soul by an angel to God's judgment. The legend of the "dispute between the soul and the body" is known in many literatures of Europe and beyond and dates back, according to the Russian researcher F. D. Batyushkov, to the first centuries of Christianity. The Russian oral tradition has numerous examples of poems with this theme. In them the angels leading the soul to paradise appear in the guise of white doves, who flew to Mount Zion and saw the soul part from the body. Doves lead their conversation, in which the soul complains to the body about its plight. If the body has but to lie in the ground, then a test awaits the soul "It is far to go, and it is hard to bear, it is hard to bear sins so serious to the Terrible Court on Judgment Day ..."

In the Serbian poem, Soul and Michael the Archangel in Paradise, placed in the collection of Vuk Karadzhich, Srpske narodne pjesme iz Hercegovine ("Serbian folk songs from Herzegovina"), it refers to the soul that has parted with the body, which is forbidden entry into paradise. The Archangel drives away the soul trying to pass itself off as righteous from the gates of paradise. It must return to the tomb, where its body is buried, and turns to him with words of reproach, which is that while on earth, it only enjoyed food and drink and did not pray to God ("Tjelo, ti si jelo, ti si pilo, ne si Boga si molilo" / "Body, You were eating, you were drinking, and weren't praying to God"). The body responds to the soul's reproach, reminding it that while it is rotting in the ground, it must "repay its debts to God." In the Belarusian version, the body objects to the soul, in turn reproaching it for its intemperance: "Ah, body, why didyou eat so early? And you, soul, why were you not patient?" In a similar way, the plot unfolds in modern transcripts of a similar verse from the Urals.

All of the above attests to the deep antiquity of the plot, which concerns not only the literature of the Slavs and Europe as a whole, but in part other literature based on the Christian tradition.

A huge number of other subjects, including those which are decidedly ancient, underlie the works of folk poetry of East Slavic literature. Their origin and interconnection within the framework of the Slavic community are still little studied. Spiritual poems as a unique area of folk culture also need further study of their deep connections with the fate of written sources and the literary context of their existence in Slavic countries. 


\section{BIBLIOGRAPHY}

Batiushkov F. Spor dushi $s$ telom v pamiatnikakh srednevekovoi literatury. Opyt istoriko-literaturnogo issledovaniia. Saint Petersburg, 1891.

Fedotov G.P. Stikhi dukhovnye (russkaia narodnaia vera po dukhovnym stikham). Moscow, 1991.

Karadžić V.S. Srpske narodne pjesme iz Hercegovine (ženske), 1866. N 332.

Sakharov $V$. Eskhatologicheskie skazaniia v drevnerusskoi pis'mennosti i vliianie ikh na narodnye dukhovnye stikhi. Tula, 1879.

\section{ILLUSTRATIONS}

1. Old Believer handwritten "hook" notated verses, 20th century. Region of Bukovina, Romania.

2. Performers of spiritual verses. Region of Bukovina, Romania. Photograph from 2010.

3. Old Believer printed poetry, 21 th century, modern "hook" notated record and the text of a spiritual verse. Old Believers of Lithuania, 21 th century.

4. Printed "hook" notated poem, 20th century.

5. Spiritual verse "On marriage in Cana of Galilee," printed "hook" notated poem, 20th century.

6-7. Illustrations for the spiritual verse "There lived a young hermit," printed "hook" notated poem, 20th century. 